\title{
0бъект виндикации:
}

\section{проблемы правоприменения}

Аннотация. В статье рассматриваются объекты гражданских прав с целью установления их возможности быть объектом виндикации. Проведен анализ таких объектов, как вещи, «бестелесные вещи», безналичные денежные средства, бездокументарные ценные бумаги, объекты интеллектуальной собственности, доли в уставном капитале обществ с ограниченной ответственностью, цифровые права, криптовалюта и др. Выявлена правовая природа указанных объектов с учетом теории права и правовых позиций судов. Как следствие, приведена аргументация относительности возможности или невозможности их виндикации по правилам ст. 301 Гражданского кодекса РФ. Рассмотрены также вопросы наличия специальных механизмов защиты прав правообладателей бездокументарных ценных бумаг и долей в уставном капитале обществ с ограниченной ответственностью на предмет их соотношения с виндикацией. Проведен анализ судебной практики по вопросу истребования объектов гражданского права из чужого незаконного владения. Сделаны выводы относительно того, какие объекты могут быть объектом виндикации непосредственно на основании ст. 301 ГК РФ, какие объекты могут быть истребованы по аналогии закона и какие объекты являются невиндицируемыми.

Ключевые слова: виндикация; истребование; защита права; вещи; бестелесные вещи; объекты гражданских прав; вещное право; гражданское право; владение; право; актуальные проблемы; цифровые права; криптовалюта.

Для цитирования: Гусева А. А. Объект виндикации: проблемы правоприменения // Актуальные проблемы российского права. - 2021. - Т. 16. - № 4. - C. 76-93. - DOI: 10.17803/1994-1471.2021.125.4.076-093.

\section{An Object of Vindication: Problems of Law Enforcement}

\author{
Anastasia A. Guseva, Graduate Student (LL.M.), National Research University Higher School of \\ Economics; Undergraduate Student, Kutafin Moscow State Law Univerity (MSAL). \\ ul. Myasnitskaya, d. 20, Moscow, Russia, 101000 \\ aguseva_legal@mail.ru
}

\begin{abstract}
The paper is devoted to examining objects of civil rights in order to establish whether it is possible to subject them to vindication. The paper analyzes such objects as things, "incorporeal things", non-cash funds, uncertified securities, intellectual property, shares in the authorized capital of limited liability companies, digital rights, cryptocurrency, etc. The author determines the legal nature of the objects under consideration with due regard to the theory of law and legal stances of courts. As a consequence, the author substantiates the relativity of the possibility or impossibility of their vindication under Art. 301 of the Civil Code of the Russian Federation. Also, the author examines the issues of existence of special mechanisms for protection of rights holders of uncertified

(C) Гусева А. А., 2021

* Гусева Анастасия Александровна, магистр права Национального исследовательского университета «Высшая школа экономики», бакалавр права Университета имени О.Е. Кутафина (МГЮА)

Мясницкая ул., д. 20, г. Москва, Россия, 101000

aguseva_legal@mail.ru
\end{abstract}


securities and shares in the authorized capital of limited liability companies to find the interrelation between them and vindication. The paper provides the analysis of judicial practice on the issue of claiming civil law objects from someone else's illegal possession. Conclusions are drawn as to which objects can be subject to vindication under Art. 301 of the Civil Code of the Russian Federation, which objects can be claimed by analogy of the law and which objects cannot be subjected to vindication.

Keywords: vindication; claim; protection of law; things; incorporeal things; objects of civil rights; property law; civil law; ownership; law; actual problems; digital rights; cryptocurrency.

Cite as: Guseva AA. Obekt vindikatsii: problemy pravoprimeneniya [An Object of Vindication: Problems of Law Enforcement]. Aktualnye problemy rossiyskogo prava. 2021;16(4):76-93. DOI: 10.17803/1994-1471.2021.125.4.076093. (In Russ., abstract in Eng.).

B индикационный иск как способ защиты нарушенного права закреплен в ст. 301 Гражданского кодекса Российской Федерации ${ }^{1}$. По своей природе он является вещно-правовым и определяется как иск невладеющего собственника к владеющему несобственнику².

В рамках спора об истребовании имущества из чужого незаконного владения исследуются следующие обстоятельства: 1) наличие у истца права собственности (иного вещного титула) на истребуемое индивидуализированное имущество; 2) наличие спорного имущества в натуре; 3) характер выбытия имущества из владения собственника (по воле / помимо воли); 4) отсутствие между истцом и ответчиком отношений обязательственного характера по поводу истребуемой вещи и 5) недобросовестность ответчика.

В то же время важную роль в споре об истребовании имущества из чужого незаконного владения играет объект виндикации, так как именно принадлежность к тому или иному объекту гражданских прав предопределяет саму возможность удовлетворения иска. В рамках данной статьи предлагается рассмотреть объект виндикации с теоретической и практической точек зрения. Поскольку если тот или иной объект не может быть объектом виндикации, то виндикационный иск не приведет к восстановлению нарушенного права и реальной защите.
Автором исследуются объекты гражданских прав на предмет их возможности быть виндицированными как таковыми на основании ст. 301, 302 ГК РФ. Анализ судебной практики показывает, что в некоторых случаях квалификация спорных отношений является неправильной, и использование вещно-правового способа защиты права не соответствует природе возникших отношений.

При этом в отношении некоторых объектов не вызывает сомнений, что они не могут быть объектом виндикации (например, нематериальные блага (п. 1 ст. 150 ГК РФ) ввиду неразрывности связи с личностью конкретного субъекта правоотношений). Поэтому они подробно не исследуются в настоящей статье.

\section{1. Вещи}

Объекты гражданских прав легально закреплены в ст. 128 ГК РФ. Первыми поименованными объектами являются вещи, которые исторически появились ранее всех остальных объектов.

В цивилистике вещь определяется как «предмет материального мира, могущий быть в обладании человека и служащий удовлетворению большинства его потребностей» ${ }^{3}$. Отмечается, что вещь рассматривается как материальный,

1 Гражданский кодекс Российской Федерации (часть первая) от 30.11.1994 № 51-Ф3 (ред. от 16.12.2019) // URL: http://ips.pravo.gov.ru:8080/document/343/ (дата обращения: 01.06.2020).

2 Обзор судебной практики по делам, связанным с истребованием жилых помещений от граждан по искам государственных органов и органов местного самоуправления (утв. Президиумом Верховного Суда РФ 25.11.2015) // Бюллетень Верховного Суда РФ. 2016. № 5.

3 Гражданское право : учебник : в 2 т. / С. С. Алексеев, О. Г. Алексеева, К. П. Беляев [и др.] ; под ред. Б. М. Гонгало. 3-е изд., перераб. и доп. М. : Статут, 2018. Т. 1. 
телесный объект имущественного оборота ${ }^{4}$, а «существенным свойством вещи [является] ее телесность, т.е. принадлежность к физическим телам ${ }^{5}$.

Еще в начале XX в. Ю. С. Гамбаров выделил следующие признаки вещи: телесность (находится в пространстве, ограничивается пространством, воспринимается непосредственного нашими органами чувств), имущественная ценность, оборотоспособность и самостоятельHOCTь ${ }^{6}$.

С. А. Синицын указывает, что «возможно разграничить вещи на две большие группы: индивидуально-определенные вещи по природе и объекты, в отношении которых действует нормативно установленный режим вещи в силу норм объективного права и которые по своим физическим характеристикам не отвечают идентифицирующим признакам вещи. Речь идет о специфических объектах (энергия, газ, ткани и органы человека, микроорганизмы) ».

В связи с вышеуказанным делением сто́ит остановиться на концепции так называемых бестелесных вещей. Некоторыми учеными высказывается позиция о возможности существования в отношении них вещных прав. Однако подобная позиция подвергается критике, в связи с чем С. В. Бородкин пишет, что «защи- та интересов обладателя прав на бестелесные объекты... в российском праве не может быть осуществлена посредством вещно-правовых способов» ${ }^{8}$.

Ю. С. Гамбаров, рассматривая римскую концепцию деления вещей на телесные (res corporales) и бестелесные (res incorporales), указывал, что европейской юриспруденцией в данные понятия вкладывается иной смысл, нежели римскими юристами. В связи с этим создается «новая категория “бестелесных вещей”, охватывающая собой все блага, не имеющие телесного бытия, но защищаемые объективным правом ${ }^{9}$. Ученый отмечал, что указанная категория является фикцией, в результате чего «бестелесные вещи» приравниваются к вещам, не обладая при этом признаками вещи, что является неправильным, поскольку «бестелесная вещь заключает в себе внутренне противоречие» ${ }^{10}$.

Например, традиционно в качестве бестелесной вещи рассматривается электрическая энергия ${ }^{11}$. А. Д. Жанэ пишет, что «с гражданско-правовой точки зрения энергию следует относить к категории вещей (так называемому бестелесному имуществу), обладающих рядом специфических свойств ${ }^{12}$. Некоторые ученые также придерживаются позиции принадлежности энергии к объектам вещного права ${ }^{13}$.

4 Лысенко А. Н. Имущество в гражданском праве России. М. : Деловой двор, 2010 ; Российское гражданское право : учебник : в 2 т. / В. С. Ем, И. А. Зенин, Н. В. Козлова [и др.] ; отв. ред. Е. А. Суханов. 2-е изд., стер. М. : Статут, 2011. Т. 1 : Общая часть. Вещное право. Наследственное право. Интеллектуальные права. Личные неимущественные права.

5 Васильев Г. С. Движимые вещи // Объекты гражданского оборота : сборник статей / отв. ред. М. А. Рожкова. М. : Статут, 2007. С. 278-325.

6 Гамбаров Ю. С. Курс гражданского права: Часть Общая. СПб., 1911. Т. 1. С. 571-574.

7 Синицын С. А. Вещь как объект гражданских прав: возможные и должные критерии идентификации // Законодательство и экономика. 2016. № 11. С. 7-17.

8 Бородкин С. В. Новый подход к классификации объектов вещных прав // Журнал российского права. 2018. № 2. С. 50-58.

9 Гамбаров Ю. С. Указ. соч. С. 577-578.

10 Гамбаров Ю. С. Указ. соч. С. 579.

11 Однако сто́ит отметить, что Ю. С. Гамбаров полагал, что электрическая энергия относится к телесным вещам (Гамбаров Ю. С. Указ. соч. С. 575).

12 Цит. по: Богданова Е. В. Проблемы предмета договора энергоснабжения // Современное право. 2006. № 5 .

13 Шведкова О. В. Энергия как объект договорных отношений: к вопросу о понятии и правовой природе // Журнал российского права. 2016. № 7. С. 52-57. 
Полагаем, что квалификация электрической энергии в качестве вещи (пусть даже бестелесной) не имеет практического смысла, поскольку применение в отношении электрической энергии вещно-правовых способов защиты (например, виндикации) представляется явно невозможным. В связи с этим рассуждения о вещной, но бестелесной природе электрической энергии бесперспективны. Для обязательственных же прав (например, для договора энергоснабжения) подобная квалификация не является необходимой.

По нашему мнению, бестелесная вещь - не что иное, как оксюморон, в результате которого предпринимается безрезультатная попытка распространить правовой режим вещи на объекты, которые вещами не являются. Поэтому полагаем, что неотъемлемым признаком категории «вещь» является ее телесность (осязаемость) ${ }^{14}$.

Установление правовой природы объекта в качестве вещи влечет важное практическое последствие - возможность существования в отношении этого объекта вещных прав. В науке подчеркивается, что объектом вещных прав могут служить только вещи, при этом только индивидуально определенные, «ибо осуществление хозяйственного господства невозможно в отношении неиндивидуализированного, абстрактно представляемого имущества» ${ }^{15}$.

В то же время нельзя не отметить, что не любой осязаемый объект гражданское право наделяет правовым режимом вещи. Это объясняется тем, что «вещь в физике» и «вещь в цивилистике» - не тождественные понятия, но, безусловно, в какой-то части пересекающиеся.

К. И. Скловский же отмечает, что «в природе вообще не существует вещей. Вещь - это продукт социальности, результат деятельности человеческого общества, направленной на разрыв природных связей и создание явлений, чуждых природе, утративших с ней связь» ${ }^{16}$. Однако, на наш взгляд, принадлежность объекта к право- вой категории вещей все-таки изначально предопределяется именно физическими свойствами.

Вещь является вещью не только в силу осязаемости, но и потому, что правопорядок признал ее таковой. Например, с точки зрения физики звезду (небесное тело) можно охарактеризовать как вещь, но для гражданского права такие вещи являются невидимыми. Фактически существует категория "физических вещей», которые для цивилистики в целом и для гражданского оборота в частности вещами не являются. В данном случае речь идет о таком признаке вещи, как оборотоспособность.

Гражданское право опосредует оборот, поэтому если какой-то объект в нем не участвует, то даже при наличии свойства телесности квалификация его в качестве вещи лишена всякого смысла. Выявление принадлежности объекта к тому или иному объекту гражданских прав в результате должно влечь практическую значимость и применимость, поскольку классификация ради классификации и квалификация ради квалификации - бессмысленные и схоластические явления.

Ученые отмечают, что «объектом виндикации во всех без исключения случаях является индивидуально-определенная вещь, сохранившаяся в натуре ${ }^{17}$ (выделено курсивом автором). Подобной категоричности можно возразить лишь в той части, что объектом виндикации может быть и родовая вещь, но индивидуализированная (то есть обладающая признаками, позволяющими ее выделить среди вещей того же рода).

Важно отметить, что момент появления вещи в российском юридическом пространстве обусловлен юридическим фактом физического первоначального создания. Недвижимая же вещь возникает только после государственной регистрации (ст. 219 ГК РФ), за исключением ряда случаев, прямо указанных в законе.

Р. С. Бевзенко отмечает, что «незарегистрированное здание же не вещь, а часть участка; на

\footnotetext{
14 Далее по тексту статьи автором под вещью понимается только телесная (осязаемая) вещь, за исключением специального указания на категорию «бестелесная вещь».

15 Суханов Е. А. К понятию вещного права // Правовые вопросы недвижимости. 2005. № 1.

16 Скловский К. И. Собственность в гражданском праве. 5-е изд., перераб. М. : Статут, 2010. С. 856.

17 Суханов Е. А. Вещное право : научно-познавательный очерк. М. : Статут, 2017.
} 
часть вещи собственности не бывает, так как не может быть вещного права на невещь» ${ }^{18}$.

Таким образом, виндикационный иск, являясь вещно-правовым, может быть предъявлен в отношении вещей, к которым относятся в том числе наличные денежные средства и документарные ценные бумаги.

Наибольшие проблемы истребования наличных денег связаны с возможностью их индивидуализации. Суды откажут в виндикации наличных денежных средств, если истцом не представлены доказательства их индивидуализации: например, доказательства того, что купюры были пронумерованы и они обладают характеристиками, позволяющими индивидуально определить каждую из купюр ${ }^{19}$.

Документарные ценными бумаги представляют собой документы, соответствующие установленным законом требованиям и удостоверяющие обязательственные и иные права (ст. 142 ГК РФ). Требование собственника (уполномоченного собственником лица) о возврате ценных бумаг носит виндикационный характер и может быть удовлетворено лишь при наличии условий, предусмотренных ст. 302 ГК РФ20.

Истребование документарных ценных бумаг от незаконного владельца осуществляется по правилам ГК РФ об истребовании вещи из чужого незаконного владения (ст. 301-303 ГК РФ) с особенностями, предусмотренными ст. 147.1 ГК РФ ${ }^{21}$. Наличные денежные средства и документарные ценные бумаги не могут быть истребованы от добросовестного приобретателя даже в том случае, когда они выбыли из владения правообладателя помимо его воли (п. 3 ст. 302 ГК РФ). Не могут быть истребованы от добросовестного приобретателя также ордерные и именные ценные бумаги, удостоверяющие денежное требование (п. 3 ст. 147.1 ГК РФ).

Сто́ит отметить, что объектом виндикации может быть только вещь в целом, истребование части вещи невозможно в силу правовой природы виндикационного иска, а также в силу того, что вещное право не может существовать в отношении части вещи. Например, не может быть объектом истребования из чужого незаконного владения часть земельного участка или часть помещения, поскольку они не являются самостоятельными объектами гражданских прав ${ }^{22}$.

\section{2. Доля в общей долевой собственности}

В науке существует несколько концепций относительно правовой природы доли в общей долевой собственности: концепции доли в праве, идеальной доли, реальной доли и доли в стоимости вещи 23 . Наибольшей же поддержки в науке получили первые две, однако и они подвергаются критики.

Не ставя своей задачей детальный анализ достоинств и недостатков указанных подходов, отметим, что в современном гражданском праве доля в праве общей долевой собственности однозначно не является вещью. В связи с этим она не может быть истребована напрямую на основании ст. 301, 302 ГК РФ.

Автор настоящей работы придерживается концепции идеальной доли, поскольку в российской цивилистике долевая собственность не

18 Бевзенко Р. С. Земельный участок с постройками на нем : Введение в российское право недвижимости. М. : М-Логос, 2017. С. 48.

19 Постановление 17 ААС от 12.04.2018 по делу № A60-41793/2017 // Доступ из справ.-правовой системы «КонсультантПлюс» (дата обращения: 01.06.2020).

20 П. 7 Информационного письма Президиума ВАС РФ от 21.04.1998 № 33 // Вестник ВАС РФ. 1998. № 6.

21 П. 42 постановления Пленума Верховного Суда РФ от 23.06.2015 № 25 «О применении судами некоторых положений раздела I части первой Гражданского кодекса Российской Федерации» // Бюллетень Верховного Суда РФ. 2015. № 8.

22 Постановление АС Северо-Кавказского округа от 17.12.2019 по делу № А53-38783/2018 ; постановление АС Северо-Кавказского округа от 06.04.2016 по делу № А32-20217/2011; постановление 6 ААС от 31.10.2019 по делу № A37-1774/2018 // Доступ из справ.-правовой системы «КонсультантПлюс» (дата обращения: 01.06.2020). 
предполагает деления вещи в натуре или выделение каких-либо частей вещи в собственность долевых сособственников.

Российское гражданское законодательство исходит именно из идеальности долей, то есть долей, существующих в правовом поле, а не в привязке к каким-либо физических границам (очертаниям) вещи. Например, в одном из дел суд указал, что по смыслу п. 1 и 2 ст. 244 ГК РФ доля в общей собственности простирается на все имущество в целом и не локализуется в какой-то конкретной его части ${ }^{24}$.

Между тем природа доли в праве общей долевой собственности имеет тесную связь с вещью, что обуславливает возможность ее виндикации на основании ст. 301, 302 ГК РФ по аналогии закона ${ }^{25}$.

\section{3. Безналичные денежные средства}

Правовая природа безналичных денежных средств долгое время вызывала дискуссии в науке. В связи с этим ряд ученых уже давно отстаивали позицию, согласно которой безналичные денежные средства являются правами требования имущественного характера, а не ве- щами и, как следствие, в их отношении не могут возникнуть никакие вещные права (в том числе право собственности) ${ }^{26}$.

На сегодняшний же момент действующая редакция ст. 128 ГК РФ однозначно относит безналичные денежные средства к имущественным правам.

Судебная практика также исходит из того, что по своей правовой природе безналичные денежные средства, существующие в виде записи на банковском счете кредитора (их обладателя), представляют собой обязательственное требование на определенную сумму к кредитной организации, в которой открыт счет ${ }^{27}$.

Е. А. Суханов отмечает невозможность использования вещно-правовых способов защиты права в отношении имущественных прав (безналичных денежных средств и т.п.) ${ }^{28}$.

Сто́ит отметить, что обязательственные права (право требования, право аренды), будучи имущественными правами, не могут быть объектом виндикации, поскольку действующим законодательством не предусмотрен такой вещноправовой способ защиты для правообладателей обязательственных прав как виндикация. Указанная позиция поддерживается и судебной практикой ${ }^{29}$.

23 Зарубин А. В. Природа доли в праве общей долевой собственности // Нотариус. 2018. № 7. С. 31-34.

24 Постановление 7 ААС от 27.03.2008 по делу № А03-8597/2007 // Доступ из справ.-правовой системы «КонсультантПлюс» (дата обращения: 01.06.2020).

25 П. 42 постановления Пленума Верховного Суда РФ № 10, Пленума ВАС РФ № 22 от 29.04.2010 «О некоторых вопросах, возникающих в судебной практике при разрешении споров, связанных с защитой права собственности и других вещных прав» // Бюллетень Верховного Суда РФ. 2010. № 7.

26 Новоселова Л. А. Денежные расчеты в предпринимательской деятельности. М., 1996. С. 37 ; Суханов Е. А. Заем и кредит. Финансирование под уступку денежного требования. Банковский вклад. Банковский счет // Хозяйство и право. 1996. № 7. С. 21-22.

27 Постановление АС Московского округа от 25.09.2018 по делу № А40-129253/2017 ; постановление АС Московского округа от 25.07.2019 по делу № A40-172988/2018; постановление АС Московского округа от 28.12.2015 по делу № А40-99892/2014; постановление АС Поволжского округа от 25.02.2016 по делу № A55-1648/2015; постановление АС Северо-Кавказского округа от 27.02.2017 по делу № А53-3967/2016 ; постановление АС Уральского округа от 03.03.2015 по делу № A76-26516/2013 ; постановление АС Уральского округа от 04.03.2013 по делу № A76-9088/2012 // Доступ из справ.-правовой системы «КонсультантПлюс» (дата обращения: 01.06.2020).

28 Суханов Е. А. Вещное право : научно-познавательный очерк. М. : Статут, 2017.

29 Постановление АС Западно-Сибирского округа от 20.08.2018 по делу № А03-339/2018; определение ВС РФ от 17.12.2018 № 304-ЭС18-20431; постановление АС Поволжского округа от 02.03.2016 по делу № А5712490/2010 // Доступ из справ.-правовой системы «КонсультантПлюс» (дата обращения: 01.06.2020). 
Относительно возможности истребования безналичных денежных средств суды отмечают, что безналичные денежные средства не являются вещами, поэтому они не могут быть объектом вещных прав ${ }^{30}$, вследствие чего не может быть признано право собственности на безналичные денежные средства ${ }^{31}$, а их возврат не может быть осуществлен посредством вещноправовых способов защиты права ${ }^{32}$.

Таким образом, природа безналичных денежных средств предопределяет невозможность их виндикации в порядке ст. 301, 302 ГК РФ.

\section{4. Бездокументарные ценными бумаги}

Бездокументарные ценные бумаги представляют собой обязательственные и иные права, которые закреплены в решении о выпуске или ином акте лица, выпустившего ценные бумаги в соответствии с требованиями закона (ст. 142 ГК РФ). В отличие от документарных, бездокументарные ценные бумаги не имеют материального носителя.

Тем не менее в практике судов можно встретить указание на «право собственности на бездокументарные ценные бумаги» ${ }^{33}$, что является ошибочным. Поскольку право собственности, будучи вещным правом, возникает в отношении вещей, к которым бездокументарные цен- ные бумаги не относятся ввиду их бестелесного существования.

В юридической литературе иногда указывается на возможность существования права собственности на иные (помимо вещей) объекты. Между тем указанная позиция вызывает сомнения у ученых ${ }^{34}$ и не поддерживается автором настоящей статьи.

Е. А. Суханов указывает, что способы гражданско-правовой защиты напрямую зависят от объекта гражданских прав, виндикация бездокументарных ценных бумаг невозможна, а «попытка распространения режима объектов вещных прав на... бездокументарные ценные бумаги... окончилась закономерной неудачей ${ }^{35}$

Рассматривая споры об истребовании бездокументарных ценных бумаг, некоторые суды ссылаются на ст. 301, 302 ГК РФ, Федеральный закон от 22.04.1996 № 39-ФЗ «О рынке ценных бумаг» ${ }^{36}$ и п. 7 информационного письма Президиума ВАС РФ от 21.04.1998 № 33, цитируя его содержание с искажением, добавляя следующую фразу «бездокументарные ценные бумаги, в число которых входят акции, по правовому статусу приравниваются к документарным ценным бумагам и могут быть предметом виндикации ${ }^{37}$. Однако в позиции ВАС РФ подобная формулировка отсутствует.

Можно выделить в том числе следующие особенности защиты нарушенных прав право-

30 Постановление 11 ААС от 14.02.2019 по делу № A65-33381/2017 // Доступ из справ.-правовой системы «КонсультантПлюс» (дата обращения: 01.06.2020).

31 Постановление 5 ААС от 12.02.2020 по делу № A51-10138/2019 // Доступ из справ.-правовой системы «КонсультантПлюс» (дата обращения: 01.06.2020).

32 Постановление 17 ААС от 22.08.2018 по делу № A71-2519/2018 // Доступ из справ.-правовой системы «КонсультантПлюс» (дата обращения: 01.06.2020).

33 Постановление 13 ААС от 20.09.2011 по делу № А21-14156/2009; постановление АС Московского округа от 31.01.2019 по делу № A40-75384/2018 // Доступ из справ.-правовой системы «КонсультантПлюс» (дата обращения: 01.06.2020).

34 Корпоративное право : учебный курс : в 2 т. / Е. Г. Афанасьева, В. А. Вайпан, А. В. Габов [и др.] ; отв. ред. И. С. Шиткина. М. : Статут, 2018. Т. 2.

35 Суханов Е. А. Указ. соч.

36 Федеральный закон от 22.04.1996 № 39-Ф3 «О рынке ценных бумаг» // СЗ РФ. 1996. № 17. Ст. 1918.

37 Постановление 5 ААС от 03.12.2015 по делу № А59-2884/2014; постановление 12 ААС от 10.05.2011 по делу № A57-3562/2008 ; постановление 5 ААС от 01.12.2016 по делу № A59-81/2016 // Доступ из справ.правовой системы «КонсультантПлюс» (дата обращения: 01.06.2020). 
обладателей бездокументарных ценных бумаг: 1) иск содержит требование о возврате ценных бумаг, а не об их истребовании (поскольку бездокументарная ценная бумага в бумажной форме не существует, хранится в виде учетной записи, то есть вещью не является); 2) правообладатель вправе требовать те ценные бумаги, в которые конвертированы принадлежащие ему бездокументарные ценные бумаги и др. Однако несмотря на обозначенные особенности, суды отмечают, что это не вступает в противоречие с правилами ст. 301, 302 ГК РФ и не исключает их применение ${ }^{38}$.

Кроме того, встречается позиция, что виндикация бездокументарных ценных бумаг не противоречит природе права собственности, а невозможность виндикации бездокументарных ценных бумаг явилась бы несоразмерным и несправедливым ограничением прав их правообладателей ${ }^{39}$

Подобный подход заслуживает критики и является, на наш взгляд, необоснованным, поскольку невозможность виндикации бездокументарных ценных бумаг не препятствует ее правообладателям защищать свои права с помощью специального механизма, предусмотренного в ст. 149.3 ГК РФ. В силу указанной нормы правообладатель, со счета которого были неправомерно списаны бездокументарные ценные бумаги, вправе требовать от лица, на счет которого ценные бумаги были зачислены, возврата такого же количества соответствующих ценных бумаг. Механизм же виндикационного иска заключается в возврате конкретной вещи, а не замены ее другой вещью или вещами того же рода и качества ${ }^{40}$. Данный факт также подтверждает необходимость разграничения виндикационного иска (ст. 301 ГК РФ) и иска о возврате бездокументарных ценных бумаг (ст. 149.3 ГК РФ), который в то же время имеет сходные условия удовлетворения.

Кроме того, виндикационный иск направлен на истребование имущества из чужого незаконного владения, что предполагает наличие возможности владеть истребуемым имуществом. Однако ВАС РФ указал, что исходя из специфики бездокументарной акции невозможно владеть ею как существующей в осязаемой форме вещью в виде физического обладания ${ }^{41}$.

Таким образом, полагаем, что бездокументарные ценные бумаги не могут быть виндицированы в порядке ст. 301, 302 ГК РФ. Для их возврата в ст. 149.3 ГК РФ предусмотрен специальный механизм. При этом представляется, что отсутствует необходимость применения виндикации по аналогии закона ввиду урегулирования механизма защиты правообладателей бездокументарных ценных бумаг.

\section{5. Интеллектуальная собственность}

Согласно статье 128 ГК РФ объектом гражданских прав являются охраняемые результаты интеллектуальной деятельности и приравненные к ним средства индивидуализации (интеллектуальная собственность). Понятие «интеллектуальная собственность», хотя и широко используется, с точки зрения теории является неточным. Это влечет лингвистическое смешение с правом собственности (вещным правом), хотя интеллектуальная собственность собственностью не является.

Результаты интеллектуальной деятельности и средства индивидуализации различны по признакам, правообладателям, правовому режиму

38 Постановление АС Дальневосточного округа от 20.03.2020 по делу № А59-7663/2018 // Доступ из справ.правовой системы «КонсультантПлюс» (дата обращения: 01.06.2020).

39 Постановление АС Поволжского округа от 17.04.2012 по делу № A57-5821/2011; постановление АС Уральского округа от 23.06.2005 по делу № A60-15758/2001 // Доступ из справ.-правовой системы «КонсультантПлюс» (дата обращения: 01.06.2020).

40 Постановление 14ААС от 21.01.2019 по делу № А05-7158/2018 // Доступ из справ.-правовой системы «КонсультантПлюс» (дата обращения: 01.06.2020).

41 Постановление Президиума ВАС РФ от 17.07.2012 № 1944/12 по делу № А55-11353/2010 // Доступ из справ.-правовой системы «КонсультантПлюс» (дата обращения: 01.06.2020). 
и др. Однако общей чертой указанных объектов является их нематериальный характер.

Ученые отмечают, что «объекты интеллектуальной собственности, представляющие собой продукты духовной, мыслительной деятельности людей, не подвержены влиянию времени, не могут погибнуть, способны одновременно удовлетворять потребности множества людей и т.п. Поэтому их правовой режим не имеет ничего общего с режимом вещей» ${ }^{42}$.

В силу особой природы интеллектуальных прав к ним неприменим виндикационный иск, что обусловлено, в частности, тем, что «объекты интеллектуальной собственности не определяются с помощью таких вещно-правовых категорий, как масса, вес, длина и т.п. ${ }^{43}$. Это также прямо следует из п. 3 ст. 1227 ГК РФ, согласно которому к интеллектуальным правам не применяются положения разд. II ГК РФ (где и расположены положения о виндикационном иске).

Нормы ч. IV ГК РФ, регулирующей права на результаты интеллектуальной деятельности и средства индивидуализации, не предусматривают их истребование из чужого незаконного владения в качестве способа защиты.

Приведем некоторые примеры из судебной практики. Суд отказал в удовлетворении иска об истребовании проектной документации, поскольку значение (потенциальную потребительскую ценность) проектной документации имеет не материальный носитель, а зафиксированная информация, а информация не виндицируется ${ }^{44}$. Проект в своей архитектурной части является объектом исключительных, но не вещных прав.
В другом деле суд отказал в виндикации интернет-сайта ввиду нематериального характера данного объекта. Однако суд указал, что присуждению в указанной части в пользу истца подлежит документ, подтверждающий принадлежность обществу определенного сайта и его право пользования им, а именно договор на разработку, обслуживание и сопровождение интернет-сайта с приложением ключей, паролей, актов выполненных работ, сертификата правообладателя ${ }^{45}$.

Также сто́ит отметить, что доменное имя хотя и не отнесено к числу результатов интеллектуальной деятельности ${ }^{46}$, но в силу того, что оно является нематериальным объектом, «права на доменное имя нельзя рассматривать в качестве разновидности права собственности ${ }^{47}$. Следовательно, виндикация доменных имен также невозможно в силу их правовой природы.

\section{6. Результаты работ и оказание услуги}

Ранее в ГК РФ к объектам гражданских прав относились «работы и услуги». На настоящий момент объектами являются результаты работ и оказание услуг ${ }^{48}$. Не ставя своей задачей проведение детального анализа различий между указанными объектами, отметим следующее.

При выполнении работы имеет значение ее результат, имеющий материальное выражение, который направлен на удовлетворение потребностей участников оборота. Услугой же является деятельность, результаты которой не имеют материального выражения, реализуются и потребля-

42 Сергеев А. П. Применение правил раздела II «Право собственности и другие вещные права» Гражданского кодекса РФ к отношениям интеллектуальной собственности // Закон. 2018. № 12. С. 87-95.

43 Право интеллектуальной собственности : учебник / Е. В. Бадулина, Д. А. Гаврилов, Е. С. Гринь [и др.] ; под общ. ред. Л. А. Новоселовой. М. : Статут, 2017. Т. 1 : Общие положения.

44 Постановление АС Северо-Западного округа от 01.11.2016 по делу № А32-34061/2015 // Доступ из справ.правовой системы «КонсультантПлюс» (дата обращения: 01.06.2020).

45 Постановление 15 ААС от 23.04.2012 по делу № А32-18386/2011 // Доступ из справ.-правовой системы «КонсультантПлюс» (дата обращения: 01.06.2020).

46 Абз. 2 п. 33 постановления Пленума Верховного Суда РФ от 23.04.2019 № 10 «О применении части четвертой Гражданского кодекса Российской Федерации» // Бюллетень Верховного Суда РФ. 2019. № 7.

47 Право в сфере Интернета : сборник статей / М. З. Али, Д. В. Афанасьев, В. А. Белов [и др.]; рук. авт. кол. и отв. ред. М. А. Рожкова. М. : Статут, 2018.

48 Изменения были внесены Федеральным законом от 02.07.2013 № 142-Ф3. 
ются в процессе осуществления этой деятельности (п. 4 и 5 ст. 38 Налогового кодекса РФ). Несмотря на то что указанные дефиниции закреплены в налоговом законодательстве, они являются релевантными и для целей гражданского права.

Отношения по поводу выполнения работ и оказания услуг опосредуются в форме разных договоров. Если заказчик требует выполнения работы, обусловленной договором подряда, то подобное требование вытекает из договорного обязательства (ст. 702 ГК РФ), а следовательно, исключается его квалификация в качестве виндикационного. Работы и услуги не могут быть объектами виндикации.

Если результатом работы является вещь, то она может быть объектом виндикации третьим лицом. Однако объектом виндикации в данном случае является не результат работ, а непосредственно сама вещь.

\section{7. Доля в уставном капитале 000}

Существует позиция, что доля в уставном капитале обществ с ограниченной ответственностью не относится к имуществу ${ }^{49}$, а является юридической фикцией, символом набора правомочий, которые имеются у участника корпорации ${ }^{50}$.

На наш взгляд, утверждение о фикционной природе доли в уставном капитале ООО является необоснованным. Доля является активным объектом гражданского оборота (может быть предметом продажи и залога, может быть включена в наследственную массу и др.). Не может существовать оборот юридических фикций. В связи с этим считаем, что необходимо согласиться с теми учеными, которые полагают, что доля в уставном капитале ООО является имуществом ${ }^{51}$.

Не вызывает споров и сомнений, что доля в уставном капитале ООО не является вещью. В то же время существуют различные подходы относительно ее правовой природы. Доля в уставном капитале ООО определяется как имущественное право ${ }^{52}$, иное имущество ${ }^{53}$, способ закрепления за лицом определенного объема имущественных и неимущественных прав и обязанностей участника общества ${ }^{54}$, комплекс имущественных и неимущественных прав 55 , совокупность прав и обязанностей, существующих в неразрывном единстве ${ }^{56}$.

49 Письмо Минфина России от 27.10.2011 № 03-04-06/4-288 // Доступ из справ.-правовой системы «КонсультантПлюс» (дата обращения: 01.06.2020).

50 Бевзенко Р. С. Комментарий к ст. 8.1 Гражданского кодекса РФ // Вестник экономического правосудия Российской Федерации. 2019. № 11. С. 127-169 ; Добровольский В. И. Применение корпоративного права: практическое руководство для корпоративного юриста. М. : Волтерс Клувер, 2008.

51 Корпоративное право : учебник / А. В. Габов, Е. П. Губин, С. А. Карелина [и др.] ; отв. ред. И. С. Шиткина. М. : Статут, 2019.

52 Постановление АС Восточно-Сибирского округа от 18.09.2015 по делу № A58-1581/2012; постановление АС Центрального округа от 15.05.2018 по делу № A83-4747/2016 ; постановление Президиума ВАС РФ от 11.10.2011 № 5950/11 по делу № А40-66193/10-83-605 // Доступ из справ.-правовой системы «КонсультантПлюс» (дата обращения: 01.06.2020) ; Бобков С. А. Уступка доли в уставном капитале общества с ограниченной ответственностью // Журнал российского права. 2002. № 7.

53 Постановление АС Дальневосточного округа от 16.05.2019 по делу № А51-19728/2014; постановление АС Центрального округа от 03.12.2018 по делу № А08-13821/2017 // Доступ из справ.-правовой системы «КонсультантПлюс» (дата обращения: 01.06.2020) ; Лапач В. А. Доля в уставном капитале как имущество // ЭЖ-Юрист. 2005. № 28 ; Новоселова Л. А. Оборотоспособность доли в уставном капитале общества с ограниченной ответственностью // Объекты гражданских прав : сборник статей. М., 2007.

54 Постановление АС Московского округа от 15.07.2014 по делу № A40-88422/2013 // Доступ из справ.правовой системы «КонсультантПлюс» (дата обращения: 01.06.2020).

55 Шевченко С. Переход долей общества с ограниченной ответственностью // Законность. 2004. № 10. С. 54-55.

56 Гонгало Б. М. Доля в уставном капитале общества с ограниченной ответственностью как объект гражданского оборота // Проблемы развития частного права : сборник статей к юбилею Владимира Саурсеевича 
Полагаем, что доля в уставном капитале ООО должна рассматриваться как иное имущество ввиду явного экономического и имущественного содержания, а также широкого толкования такой категории, как «иное имущество».

Б. М. Гонгало подчеркивает, что доля в уставном капитале ООО не является вещью, в связи с чем делает «важный практический вывод: нормы законодательства о собственности... к ней отношения не имеют ${ }^{57}$.

Тем не менее в судебных актах можно встретить формулировку «право собственности на долю в уставном капитале ООО ${ }^{58}$, что является ошибочным (по тем же причинам, что были ранее указаны относительно бездокументарных ценных бумаг).

Для истребования долей в уставном капитале 000 предусмотрен механизм ${ }^{59}$ в ч. 17 ст. 21 Федерального закона от 08.02.1998 № 14-Ф3 «Об обществах с ограниченной ответственностью ${ }^{60}$. В судебной практике, на наш взгляд, происходит необоснованное смешение указанного механизма и ст. 301, 302 ГК РФ.

Суды, мотивируя принятое решение одновременно нормами о восстановлении корпора- тивного контроля и нормами о виндикации, указывают, что законодательством предусмотрен специальный способ защиты прав лица, у которого доля в уставном капитале хозяйственного общества изъята по незаконным основаниям, но при этом отмечают со ссылкой на позицию ВАС РФ ${ }^{61}$ материально-правовую квалификацию требования как виндикационного ${ }^{62}$.

Между тем доля в уставном капитале ООО, не являясь вещью, объектом виндикации быть не может ${ }^{63}$. А положения ст. 301, 302 ГК РФ могут быть применены лишь по аналогии закона. В то же время считаем излишними ссылки на положения гражданского законодательства об истребовании имущества из чужого незаконного владения, поскольку Федеральным законом «Об обществах с ограниченной ответственностью» предусмотрен детальный механизм защиты.

В практике имеются судебные акты, мотивированные исключительно положениями корпоративного законодательства ${ }^{64}$. Подчеркивается существование специального способа защиты прав лица, утратившего долю в уставном капитале ООО, представляющего собой восстановление положения, существовавшего до нару-

Ема / С. С. Алексеев, А. В. Асосков, В. Ю. Бузанов [и др.] ; отв. ред. Е. А. Суханов, Н. В. Козлова. М. : Статут, 2011.

57 Гонгало Б. М. Указ. соч.

58 Постановление 6 ААС от 12.08.2019 по делу № A20-5782/2018 // Доступ из справ.-правовой системы «КонсультантПлюс» (дата обращения: 01.06.2020).

59 Указанный механизм введен Федеральным законом от 30.12.2008 № 312-Ф3 (СЗ РФ. 2009. № 1. СТ. 20), вступившим в силу с 1 июля 2009 г.

60 Федеральный закон от 08.02.1998 № 14-ФЗ «Об обществах с ограниченной ответственностью» // СЗ РФ. 1998. № 7. Ст. 785.

61 Постановление Президиума ВАС РФ от 29.08.2006 № 1877/06 по делу № A40-10648/05-100-77 ; постановление Президиума ВАС РФ от 14.07.2009 № 5194/09 по делу № А60-10028/2008-С2 // Доступ из справ.правовой системы «КонсультантПлюс» (дата обращения: 01.06.2020).

62 Постановление 14 ААС от 01.12.2015 по делу № А05-1215/2015 ; постановление АС Северо-Западного округа от 16.01.2017 по делу № А56-73759/2015; постановление АС Дальневосточного округа от 25.08.2016 по делу № А04-8228/2015 // Доступ из справ.-правовой системы «КонсультантПлюс» (дата обращения: 01.06.2020).

63 Постановление АС Уральского округа от 26.04.2004 по делу № А60-23684/2003 ; постановление АС Восточно-Сибирского округа от 30.11.2004 по делу № A74-2109/2004 // Доступ из справ.-правовой системы «КонсультантПлюс» (дата обращения: 01.06.2020).

64 Постановление АС Московского округа от 15.08.2018 по делу № A40-169075/2016 ; постановление АС Северо-Западного округа от 27.02.2018 по делу № A21-565/2016 // Доступ из справ.-правовой системы «КонсультантПлюс» (дата обращения: 01.06.2020). 
шения права. В связи с вышеизложенным, на наш взгляд, споры, связанные с истребованием доли в уставном капитале ООО, должны рассматриваться исключительно как требования о восстановлении корпоративного контроля (п. 3 ст. 65.2 ГК РФ).

\section{8. Цифровые права}

Цифровые права являются новым объектом гражданских прав (ст. 141.1 ГК РФ) ${ }^{65}$. В науке критикуется новый объект как с точки зрения самой концепции, так и с точки зрения итогового текста закона.

С. В. Сарбаш отмечает, что законодательные новеллы являются «фундаментальной законодательной ошибкой и не выдерживают критики перед лицом теории гражданского права ${ }^{66}$. Не вдаваясь в оценку целесообразности введения цифровых прав в гражданское законодательство, в рамках данной статьи рассмотрим их правовую природу для целей выявления возможности или невозможности виндикации.

Под цифровыми правами понимаются названные в таком качестве в законе обязательственные и иные права, содержание и условия осуществления которых определяются в соответствии с правилами информационной системы, отвечающей установленным законом признакам.

Цифровые права подчинены принципу легалитета, который требует закрепления конкретных их видов. В связи с этим ст. 141.1 ГК РФ фактически имеет рамочный характер, поскольку многие аспекты должны быть урегулированы другим законом ${ }^{67}$.

Цифровые права не обладают самостоятельной, уникальной природой, т.к. фактически предоставляют лишь форму их существования (форму оформления). В ГК РФ указано, что к ним относятся обязательственные и иные права. Ввиду отсутствия практики применения законодательства в данной сфере и активного оборота цифровых прав сложно сказать, какие «иные права» имел в виду законодатель (вещные, корпоративные или исключительные).

Цифровые обязательственные права не могут быть объектом виндикации, поскольку, как ранее указывалось, действующим законодательством не предусмотрен такой вещноправовой способ защиты для правообладателей обязательственных прав, как виндикация. Кроме того, на наш взгляд, все цифровые права не могут быть объектом виндикации, учитывая их сходство с бездокументарными ценными бумагами, а также их нематериальных характер.

\section{9. Криптовалюта}

Среди ученых и практикующих юристов ведутся дискуссии относительно места криптовалюты в системе объектов гражданских прав.

В пояснительной записке к проекту федерального закона ${ }^{68}$, которым в ГК РФ введены цифровые права как новый объект гражданских прав, указывалось, что криптовалюта и токены являются новыми объектами экономических отношений, при этом криптовалюта рассматри-

65 Цифровые права введены в ГК РФ Федеральным законом от 18.03.2019 № 34-ФЗ (СЗ РФ. 2019. № 12. Ст. 1224), вступившим в силу с 1 октября 2019 г.

66 Новоселова Л. А., Габов А. В., Савельев А. И., Генкин А. С., Сарбаш С. В., Асосков А. В., Семенов А. В., Янковский Р. М., Журавлев А. А., Толкачев А. Ю., Камелькова А. В., Успенский М. А., Крупенин Р. А., Кислый В. А., Жужжалов М. Б., Попов В. А., Аграновская М. А. Цифровые права как новый объект гражданского права // Закон. 2019. № 5. С. 31-54.

67 Ряд аспектов будет урегулирован Федеральным законом от 31.07.2020 № 259-Ф3 «О цифровых финансовых активах, цифровой валюте и о внесении изменений в отдельные законодательные акты Российской Федерации» (СЗ РФ. 2020. № 31 (ч. І). СТ. 5018).

68 Проект закона № 424632-7 «О внесении изменений в части первую, вторую и статью 1124 части третьей Гражданского кодекса Российской Федерации // URL: https://sozd.duma.gov.ru/bill/424632-7 (дата обращения: 19.05.2020). 
валась как цифровые деньги. Однако в окончательной редакции криптовалюта так и не была включена в текст закона.

В то же время нельзя не отметить, что 31 июля 2020 г. был принят Федеральный закон № 259-Ф3 «О цифровых финансовых активах, цифровой валюте и о внесении изменений в отдельные законодательные акты Российской Федерации», закрепивший новое для российского права понятие - цифровая валюта. Данный Федеральный закон вступает в силу с 1 января 2021 г., за исключением одной нормы, вступающей в силу с 10 января 2021 г.

Цифровая валюта представляет собой совокупность электронных данных (цифрового кода или обозначения), отвечающих определенным признакам, указанным в п. 3 ст. 1 Федерального закона «О цифровых финансовых активах...». Между тем, на наш взгляд, закрепленное в Законе определение не решает проблему квалификации цифровой валюты в качестве объекта гражданских прав.

Законом (п. 5 ст. 14) также закреплено, что российские лица ${ }^{69}$ не вправе принимать цифровую валюту в качестве встречного предоставления за передаваемые ими (им) товары, выполняемые ими (им) работы, оказываемые ими (им) услуги или иного способа, позволяющего предполагать оплату цифровой валютой товаров (работ, услуг). Фактически указанная норма ставит под сомнение не только оборотоспособность цифровой валюты, но и целесообразность закрепления ее в законе.

Учитывая то, что данный Закон, на наш взгляд, не только не решил, но еще больше запутал регулирование в данной области, полагаем необходимым остановиться на вопросе анализа криптовалюты с точки зрения граж- данского права исключительно на основе норм ГК РФ.

Полагаем, что не требуется специальное указание гражданского законодательства для признания криптовалюты объектом гражданских прав ввиду реально существующего их экономического оборота, а ключевой вопрос заключается лишь в том, к какому именно объекту ее следует относить. В то же время практика арбитражных судов заставляет многих юристов обосновывать и аргументировать, что криптовалюта является объектом гражданских прав, поскольку позиция некоторых судей заключается в том, что статья 128 ГК РФ прямо не называет криптовалюту в качестве объекта гражданских прав, в связи чем криптовалюта к ним не относится и находится вне правового поля на территории Российской Федерации ${ }^{70}$. Подобная позиция является, на наш взгляд, неправильной, так как основана на непонимании открытого перечня такого объекта, как имущество (ввиду установления в статье категории «иное имущество»).

В науке предлагается несколько подходов к определению правовой природы криптовалюты.

По мнению А. И. Савельева, криптовалюта не является вещью, результатом работ или оказания услуг, результатом интеллектуальной деятельности, нематериальным благом, законным средством платежа, денежным суррогатом, электронным денежным средством, бездокументарной ценной бумагой, валютной ценностью ${ }^{71}$. По мнению ученого, криптовалюта могла бы быть отнесена к такому объекту, как информация, однако в настоящее время она не поименована как объект гражданских прав, в связи с чем в силу положений действующей

69 Под «российскими лицами» автором статьи понимаются юридические лица, личным законом которых является российское право; филиалы, представительства и иные обособленные подразделения международных организаций и иностранных юридических лиц, компаний и других корпоративных образований, обладающих гражданской правоспособностью, созданные на территории Российской Федерации; физические лица, фактически находящиеся в Российской Федерации не менее 183 дней в течение 12 следующих подряд месяцев.

70 Постановление АС Поволжского округа от 18.10.2018 по делу № A57-21957/2017 // Доступ из справ.правовой системы «КонсультантПлюс» (дата обращения: 01.06.2020).

71 Савельев А. И. Криптовалюты в системе объектов гражданских прав // Закон. 2017. № 8. С. 136-153. 
ст. 128 ГК РФ криптовалюта относится к иному имуществу.

В судебной практике также высказывается правовая позиция, что криптовалюта является иным имуществом, поскольку эта категория допускает максимально широкое толкование, и в силу диспозитивности норм гражданского права в ГК РФ отсутствует закрытый перечень объектов гражданских прав ${ }^{72}$.

Е. Н. Абрамова определяет правовую природу криптовалюты как квазивещь ${ }^{73}$. А. В. Саженов предлагает рассматривать криптовалюту как бестелесную вещь, обосновывая свою позицию тем, что вещь «не следует сводить исключительно к материальному миру ${ }^{74}$.

С подобной квалификацией не согласна Л. Г. Ефимова, которая под вещью понимает «материальные физически осязаемые объекты», а термин res incorporales, по ее мнению, является не более чем фигурой речи. Предлагается рассматривать криптовалюту как совершенно новый объект гражданского права ${ }^{75}$.

Некоторые ученые придерживаются точки зрения, что нельзя квалифицировать криптовалюту как объект sui generis. При этом отмечается, что криптовалюта может иметь признаки безналичных денег и бездокументарных ценных бумаг. Поэтому наиболее рациональным вариантом авторы считают распространение на криптовалюту правового режима указанных объектов ${ }^{76}$.

Криптовалюта имеет явное экономическое содержание и постепенно включается в гражданский оборот, в связи с этим представляется логичным рассматривать ее в качестве иного имущества.
По нашему мнению, криптовалюта однозначно не относится к такому объекту гражданских прав, как вещи. Это обусловлено классическим представлением о вещи и необходимом ее телесном (осязаемом) содержании. Квалификация же криптовалюты в качестве бестелесной вещи или квазивещи не имеет практических последствий для регулирования отношений и разрешения споров. В связи с этим возникает вопрос: зачем квалифицировать какой-либо объект как вещь, если возникновение в отношении него вещных прав и применение вещно-правовых способов защиты права по меньшей мере является сомнительным, а по большей мере - противоречит их сущности?

По мнению А. В. Саженова, «применение виндикации к криптовалютам... представляется возможным только в случае, если криптовалюты не будут смешиваться с иными криптовалютами так, чтобы их было невозможно идентифицировать. Если технически нельзя совершить обратную транзакцию тех же самых единиц криптовалюты, что ранее были зачислены, виндикация будет невозможной $)^{77}$.

Однако, на наш взгляд, учитывая, что в отношении криптовалюты не возникают вещные права, виндикационный иск также недоступен для защиты нарушенных прав. Подобного мнения придерживается и А. И. Савельев ${ }^{78}$.

Например, арбитражный суд отказал в удовлетворении иска об обязании ответчиков обеспечить возврат криптовалюты на цифровые кошельки контрибьюторов пропорционально размеру вклада каждого контрибьютора, поскольку такой способ защиты права не предусмотрен

72 Постановление 9 ААС от 15.05.2018 по делу № А40-124668/2017 // Доступ из справ.-правовой системы «КонсультантПлюс» (дата обращения: 01.06.2020).

73 Абрамова Е. Н. К вопросу о соотношении электронных денег и криптовалюты // Конкурентное право. 2019. № 3. С. 18-22.

74 Саженов А. В. Криптовалюты: дематериализация категории вещей в гражданском праве // Закон. 2018. № 9. С. 106-121.

75 Ефимова Л. Г. Криптовалюты как объект гражданского права // Хозяйство и право. 2019. № 4. С. 17-25.

76 Арнаутов Д. Р., Ерохина М. Г. Цифровые активы в системе российского права // Российский юридический журнал. 2019. № 4. С. 148-157.

77 Саженов А. В. Указ. соч. С. 106-121.

78 Савельев А. И. Указ. соч. С. 136-153. 
ст. 12 ГК РФ79. Суд также отметил, что истец не обращается с исковым заявлением об истребовании из чужого незаконного владения флешек с доступом доступ к криптокошельку (передать пароль). При этом в судебном акте интересны рассуждения суда о правовой и технической природе криптовалюты: суд указывает, что понятие криптовалюты действующим законодательством не определено, но в то же время указывает, что она (криптовалюта) не может быть не чем иным, кроме как иным имуществом.

В другом деле суд, рассмотрев заявление арбитражного управляющего по правилам ст. 66 АПК РФ, определил «истребовать имущество (биткоины) для включения в конкурсную массу, а именно: обязать передать данные доступа к биткоин-кошельку (сайт доступа к кошельку, уникальный номер кошелька, пароль к кошельку) ${ }^{80}$.

Виндикация же самой криптовалюты невозможна ввиду ее бестелесного существования, невозможности владения ею и несущестования в отношении нее вещных прав.

Кроме того, сто́ит отметить, что в силу п. 6 ст. 14 Федерального закона «О цифровых финансовых активах...» требования российских лиц, связанные с обладанием цифровой валютой, подлежат судебной защите только при условии информирования ими о фактах обладания цифровой валютой и совершения гражданско-правовых сделок и (или) операций с цифровой валютой в порядке, установленном законодательством Российской Федерации о налогах и сборах. На наш взгляд, подобная формулировка значительно ограничивает право на судебную защиту и влечет чрезмерные риски для потенциальных приобретателей цифровой валюты, превращая обязательства с ее участием в натуральные.

\section{Выводы}

Резюмируя все вышеизложенное, можно отметить, что объектом виндикации могут быть только вещи (индивидуально-определенные или родовые, но индивидуализированные).

В арбитражном процессе требования истца к ответчику должны быть указаны со ссылкой на законы и иные нормативные правовые акты (п. 4 ч. 2 ст. 125 Арбитражного процессуального кодекса РФ). Однако это не препятствует арбитражному суду руководствоваться иными нормами при принятии решения с указанием мотивов, по которым суд не применил законы и иные нормативные правовые акты, на которые ссылались лица, участвующие в деле (п. 3 ч. 4 ст. 170 АПК РФ).

В случае, если истцом заявлено требование со ссылкой на ст. 301, 302 ГК РФ в отношении объектов, которые не имеют материального, вещно-правового субстрата, суд обязан мотивировать принятое им решение только теми нормами права, которые предусматривают специальный механизм защиты объектов гражданских прав (бездокументарных ценных бумаг, долей в уставном капитале ООО). Ссылка же на ст. 301, 302 ГК РФ для истребования не вещей, а иных объектов может быть лишь субсидиарной, по аналогии закона в том случае, если это обусловлено необходимостью, вызвано отсутствием прямой нормы и не противоречит сущности виндикации (например, виндикация долей в общей долевой собственности).

Действующая редакция ст. 301 ГК РФ закрепляет, что собственник вправе истребовать свое имущество из чужого незаконного владения. Проект изменений в ГК РФ в части вещных прав предлагал закрепить в ст. 227, что собственник вправе истребовать вещь из чужого незаконного владения ${ }^{81}$. При этом законопроектом предлага-

79 Постановление 9 ААС от 04.02.2020 по делу № А40-164942/2019 // Доступ из справ.-правовой системы «КонсультантПлюс» (дата обращения: 01.06.2020).

80 Определение АС г. Москвы от 18.02.2019 по делу № A40-12639/2016, оставленное без изменения постановлением 9 ААС от 18.04.2019 по делу № A40-12639/2016 // Доступ из справ.-правовой системы «КонсультантПлюс» (дата обращения: 01.06.2020).

81 Проект закона № 47538-6 «О внесении изменений в части первую, вторую, третью и четвертую Гражданского кодекса Российской Федерации, а также в отдельные законодательные акты Российской Федерации» // URL: https://sozd.duma.gov.ru/bill/47538-6 (дата обращения: 01.06.2020). 
лось прямо закрепить, что объектами вещных прав являются вещи (ст. 222 проекта).

Представляется, что предлагаемая проектом изменений в ГК РФ формулировка виндикационного иска является более удачной, а прямое указание на объекты вещных прав отвечает потребностям правоприменения во избежание неточностей при квалификации отношений, в связи с чем указанные нормы, на наш взгляд, подлежат включению в гражданское законодательство в ходе реформы вещных прав в будущем.

\section{БИБЛИОГРАФИЯ}

1. Абрамова Е. Н. К вопросу о соотношении электронных денег и криптовалюты // Конкурентное право. 2019. - № 3. - С. 18-22.

2. Арнаутов Д. Р., Ерохина М. Г. Цифровые активы в системе российского права // Российский юридический журнал. - 2019. - № 4. - С. 148-157.

3. Бевзенко Р. С. Земельный участок с постройками на нем: введение в российское право недвижимости. - М. : М-Логос, 2017. - 80 с.

4. Бевзенко Р. С. Комментарий к ст. 8.1 Гражданского кодекса РФ // Вестник экономического правосудия Российской Федерации. - 2019. - № 11. - С. 127-169.

5. Бобков С. А. Уступка доли в уставном капитале общества с ограниченной ответственностью // Журнал российского права. - 2002. - № 7.

6. Богданова Е. В. Проблемы предмета договора энергоснабжения // Современное право. - 2006. № 5.

7. Бородкин С. В. Новый подход к классификации объектов вещных прав // Журнал российского права. 2018. - № 2. - С. 50-58.

8. Васильев Г. С. Движимые вещи // Объекты гражданского оборота : сборник статей / отв. ред. М. А. Рожкова. - М. : Статут, 2007. - С. 278-325.

9. Гамбаров Ю. С. Курс гражданского права : Часть Общая. - СПб., 1911. - Т. 1.

10. Гонгало Б. М. Доля в уставном капитале общества с ограниченной ответственностью как объект гражданского оборота // Проблемы развития частного права : сборник статей к юбилею Владимира Саурсеевича Ема / С. С. Алексеев, А. В. Асосков, В. Ю. Бузанов [и др.] ; отв. ред. Е. А. Суханов, Н. В. Козлова. - М. : Статут, 2011.

11. Гражданское право : учебник : в 2 т. / С. С. Алексеев, О. Г. Алексеева, К. П. Беляев [и др.] ; под ред. Б. М. Гонгало. - 3-е изд., перераб. и доп. - М. : Статут, 2018. - Т. 1. - 528 с.

12. Добровольский В. И. Применение корпоративного права: практическое руководство для корпоративного юриста. - М. : Волтерс Клувер, 2008. - 576 с.

13. Ефимова Л. Г. Криптовалюты как объект гражданского права // Хозяйство и право. - 2019. - № 4. C. $17-25$.

14. Зарубин А. В. Природа доли в праве общей долевой собственности // Нотариус. - 2018. - № 7. C. $31-34$.

15. Корпоративное право : учебник / А. В. Габов, Е. П. Губин, С. А. Карелина [и др.] ; отв. ред. И. С. Шиткина. - М. : Статут, 2019. - 735 с.

16. Корпоративное право : учебный курс : в 2 т. / Е. Г. Афанасьева, В. А. Вайпан, А. В. Габов [и др.] ; отв. ред. И. С. Шиткина. - М. : Статут, 2018. - Т. 2. - 990 с.

17. Лысенко А. Н. Имущество в гражданском праве России. - М. : Деловой двор, 2010. - 200 с.

18. Новоселова Л. А. Денежные расчеты в предпринимательской деятельности. - М., 1996. - 160 с.

19. Новоселова Л. А., Габов А. В., Савельев А. И., Генкин А. С., Сарбаш С. В., Асосков А. В., Семенов А. В., Янковский Р. М., Журавлев А. А., Толкачев А. Ю., Камелькова А. В., Успенский М. А., Крупенин Р. А., 
Кислый В. А., Жужжалов М. Б., Попов В. А., Аграновская М. А. Цифровые права как новый объект гражданского права // Закон. - 2019. - № 5. - С. 31-54.

20. Право в сфере Интернета : сборник статей / М. 3. Али, Д. В. Афанасьев, В. А. Белов [и др.]; рук. авт. кол. и отв. ред. М. А. Рожкова. - М. : Статут, 2018. - 528 с.

21. Право интеллектуальной собственности : учебник / Е. В. Бадулина, Д. А. Гаврилов, Е. С. Гринь [и др.] ; под общ. ред. Л. А. Новоселовой. - М. : Статут, 2017. - Т. 1 : Общие положения. - 512 с.

22. Российское гражданское право : учебник : в 2 т. / В. С. Ем, И. А. Зенин, Н. В. Козлова [и др.] ; отв. ред. Е. А. Суханов. - 2-е изд., стереотип. - М. : Статут. - 2011. - Т. 1 : Общая часть. Вещное право. Наследственное право. Интеллектуальные права. Личные неимущественные права. - 958 с.

23. Савельев А. И. Криптовалюты в системе объектов гражданских прав // Закон. - 2017. - № 8. C. 136-153.

24. Саженов А. В. Криптовалюты: дематериализация категории вещей в гражданском праве // Закон. 2018. - № 9. - С. 106-121.

25. Сергеев А. П. Применение правил раздела II «Право собственности и другие вещные права» Гражданского кодекса РФ к отношениям интеллектуальной собственности // Закон. - 2018. - № 12. - С. 87-95.

26. Скловский К. И. Собственность в гражданском праве. - 5-е изд., перераб. - М. : Статут, 2010. - 893 с.

27. Синицын С. А. Вещь как объект гражданских прав: возможные и должные критерии идентификации // Законодательство и экономика. - 2016. - № 11. - С. 7-17.

28. Суханов Е. А. Вещное право : научно-познавательный очерк. - М. : Статут, 2017. - 560 с.

29. Суханов Е. А. Заем и кредит. Финансирование под уступку денежного требования. Банковский вклад. Банковский счет // Хозяйство и право. - 1996. - № 7.

30. Суханов Е. А. К понятию вещного права // Правовые вопросы недвижимости. - 2005. - № 1.

31. Шведкова О. В. Энергия как объект договорных отношений: к вопросу о понятии и правовой природе // Журнал российского права. - 2016. - № 7. - С. 52-57.

32. Шевченко С. Переход долей общества с ограниченной ответственностью // Законность. - 2004. № 10. - C. 54-55.

Материал поступил в редакцию 18 июня 2020 г.

\section{REFERENCES (TRANSLITERATION)}

1. Abramova E. N. K voprosu o sootnoshenii elektronnyh deneg i kriptovalyuty // Konkurentnoe pravo. 2019. - № 3. - S. 18-22.

2. Arnautov D. R., Erohina M. G. Cifrovye aktivy v sisteme rossijskogo prava // Rossijskij yuridicheskij zhurnal. 2019. - № 4. - S. 148-157.

3. Bevzenko R. S. Zemel'nyj uchastok s postrojkami na nem: vvedenie v rossijskoe pravo nedvizhimosti. - M. : M-Logos, 2017. - $80 \mathrm{~s}$.

4. Bevzenko R. S. Kommentarij k st. 8.1 Grazhdanskogo kodeksa RF // Vestnik ekonomicheskogo pravosudiya Rossijskoj Federacii. - 2019. - № 11. - S. 127-169.

5. Bobkov S. A. Ustupka doli v ustavnom kapitale obshchestva s ogranichennoj otvetstvennost'yu // Zhurnal rossijskogo prava. - 2002. - № 7 .

6. Bogdanova E. V. Problemy predmeta dogovora energosnabzheniya // Sovremennoe pravo. - 2006. - № 5.

7. Borodkin S. V. Novyj podhod k klassifikacii ob"ektov veshchnyh prav // Zhurnal rossijskogo prava. - 2018. № 2. - S. 50-58.

8. Vasil'ev G. S. Dvizhimye veshchi // Ob"ekty grazhdanskogo oborota : sbornik statej / otv. red. M. A. Rozhkova. - M. : Statut, 2007. - S. 278-325.

9. Gambarov Yu. S. Kurs grazhdanskogo prava : Chast' Obshchaya. - SPb., 1911. - T. 1. 
10. Gongalo B. M. Dolya v ustavnom kapitale obshchestva s ogranichennoj otvetstvennost'yu kak ob"ekt grazhdanskogo oborota // Problemy razvitiya chastnogo prava : sbornik statej k yubileyu Vladimira Saurseevicha Ema / S. S. Alekseev, A. V. Asoskov, V. Yu. Buzanov [i dr.] ; otv. red. E. A. Suhanov, N. V. Kozlova. M. : Statut, 2011.

11. Grazhdanskoe pravo : uchebnik : v 2 t. / S. S. Alekseev, O. G. Alekseeva, K. P. Belyaev [i dr.] ; pod red. B. M. Gongalo. - 3-e izd., pererab. i dop. - M. : Statut, 2018. - T. 1. - $528 \mathrm{~s}$.

12. Dobrovol'skij V. I. Primenenie korporativnogo prava: prakticheskoe rukovodstvo dlya korporativnogo yurista. M. : Volters Kluver, 2008. - $576 \mathrm{~s}$.

13. Efimova L. G. Kriptovalyuty kak ob"ekt grazhdanskogo prava // Hozyajstvo i pravo. — 2019. — № 4. S. 17-25.

14. Zarubin A. V. Priroda doli v prave obshchej dolevoj sobstvennosti // Notarius. - 2018. — № 7. - S. 31 -34.

15. Korporativnoe pravo : uchebnik / A. V. Gabov, E. P. Gubin, S. A. Karelina [i dr.] ; otv. red. I. S. Shitkina. - M. : Statut, 2019. - $735 \mathrm{~s}$.

16. Korporativnoe pravo : uchebnyj kurs : v 2 t. / E. G. Afanas'eva, V. A. Vajpan, A. V. Gabov [i dr.] ; otv. red. I. S. Shitkina. - M. : Statut, 2018. - T. 2. - $990 \mathrm{~s}$.

17. Lysenko A. N. Imushchestvo v grazhdanskom prave Rossii. - M. : Delovoj dvor, 2010. - $200 \mathrm{~s}$.

18. Novoselova L. A. Denezhnye raschety v predprinimatel'skoj deyatel'nosti. - M., 1996. - $160 \mathrm{~s}$.

19. Novoselova L. A., Gabov A. V., Savel'ev A. I., Genkin A. S., Sarbash S. V., Asoskov A. V., Semenov A. V., Yankovskij R. M., Zhuravlev A. A., Tolkachev A. Yu., Kamel'kova A. V., Uspenskij M. A., Krupenin R. A., Kislyj V. A., Zhuzhzhalov M. B., Popov V. A., Agranovskaya M. A. Cifrovye prava kak novyj ob"ekt grazhdanskogo prava // Zakon. - 2019. - № 5. - S. 31-54.

20. Pravo v sfere Interneta : sbornik statej / M. Z. Ali, D. V. Afanas'ev, V. A. Belov [i dr.]; ruk. avt. kol. i otv. red. M. A. Rozhkova. - M. : Statut, 2018. - $528 \mathrm{~s}$.

21. Pravo intellektual'noj sobstvennosti : uchebnik / E. V. Badulina, D. A. Gavrilov, E. S. Grin' [i dr.] ; pod obshch. red. L. A. Novoselovoj. - M. : Statut, 2017. - T. 1 : Obshchie polozheniya. - $512 \mathrm{~s}$.

22. Rossijskoe grazhdanskoe pravo : uchebnik : v 2 t. / V. S. Em, I. A. Zenin, N. V. Kozlova [i dr.] ; otv. red. E. A. Suhanov. - 2-e izd., stereotip. - M. : Statut. - 2011. - T. 1 : Obshchaya chast'. Veshchnoe pravo. Nasledstvennoe pravo. Intellektual'nye prava. Lichnye neimushchestvennye prava. $-958 \mathrm{~s}$.

23. Savel'ev A. I. Kriptovalyuty v sisteme ob"ektov grazhdanskih prav // Zakon. - 2017. - № 8. - S. $136-153$.

24. Sazhenov A. V. Kriptovalyuty: dematerializaciya kategorii veshchej v grazhdanskom prave // Zakon. - 2018. № 9. - S. 106-121.

25. Sergeev A. P. Primenenie pravil razdela II «Pravo sobstvennosti i drugie veshchnye prava» Grazhdanskogo kodeksa RF k otnosheniyam intellektual'noj sobstvennosti // Zakon. - 2018. - № 12. - S. 87-95.

26. Sklovskij K. I. Sobstvennost' v grazhdanskom prave. - 5-e izd., pererab. - M. : Statut, 2010. - $893 \mathrm{~s}$.

27. Sinicyn S. A. Veshch' kak ob"ekt grazhdanskih prav: vozmozhnye i dolzhnye kriterii identifikacii // Zakonodatel'stvo i ekonomika. - 2016. - № 11. - S. 7-17.

28. Suhanov E. A. Veshchnoe pravo : nauchno-poznavatel'nyj ocherk. - M. : Statut, 2017. - $560 \mathrm{~s}$.

29. Suhanov E. A. Zaem i kredit. Finansirovanie pod ustupku denezhnogo trebovaniya. Bankovskij vklad. Bankovskij schet // Hozyajstvo i pravo. - 1996. - № 7.

30. Suhanov E. A. K ponyatiyu veshchnogo prava // Pravovye voprosy nedvizhimosti. - 2005. - № 1.

31. Shvedkova O. V. Energiya kak ob"ekt dogovornyh otnoshenij: k voprosu o ponyatii i pravovoj prirode // Zhurnal rossijskogo prava. - 2016. - № 7. - S. 52-57.

32. Shevchenko S. Perekhod dolej obshchestva s ogranichennoj otvetstvennost'yu // Zakonnost'. - 2004. № $10 .-$ S. 54-55. 